\title{
Effects of lamivudine on serum albumin levels correlate with pretreatment HBV-DNA levels in cirrhotic patients
} Makoto Nakamuta ${ }^{1}$, Kazuhiro Kotoh ${ }^{1}$, Munechika Enjoji ${ }^{* 1}$, Eiji Kajiwara ${ }^{3}$, Junya Shimono ${ }^{4}$, Akihide Masumoto ${ }^{5}$, Toshihiro Maruyama ${ }^{6}$, Norihiro Furusyo ${ }^{7}$, Hideyuki Nomura ${ }^{8}$, Hironori Sakai ${ }^{9}$, Kazuhiro Takahashi10, Koichi Azuma ${ }^{11}$, Shinji Shimoda ${ }^{12}$, Yuichi Tanabe ${ }^{2}$ and Jun Hayashi ${ }^{7}$

Address: ${ }^{1}$ Department of Medicine and Bioregulatory Science, Graduate School of Medical Sciences, Kyushu University, Japan, ${ }^{2}$ Department of Medicine, Fukuoka City Hospital, Fukuoka, Japan, ${ }^{3}$ Department of Internal Medicine, Nippon Steel Yawata Memorial Hospital, Kitakyushu, Japan, ${ }^{4}$ Department of Medicine, Yahata Saiseikai Hospital, Kitakyushu, Japan, ${ }^{5}$ Department of Clinical Research, National Hospital Organization Kokura Hospital, Kitakyushu, Japan, ${ }^{6}$ Department of Medicine, Kitakyushu Municipal Medical Center, Kitakyushu, Japan, ${ }^{7}$ Department of Environmental Medicine and Infectious Diseases, Graduate School of Medical Sciences, Kyushu University, Japan, ${ }^{8}$ Department of Internal Medicine, Shin-Kokura Hospital, Kitakyushu, Japan, ${ }^{9}$ Department of Gastroenterology, National Hospital Organization Kyushu Medical Center, Fukuoka, Japan, ${ }^{10}$ Department of Medicine, Hamanomachi Hospital, Fukuoka, Japan, ${ }^{11}$ Department of Medicine and Clinical Science, Graduate School of Medical Sciences, Kyushu University, Japan and ${ }^{12}$ Department of Medicine and Biosystemic Science, Graduate School of Medical Sciences, Kyushu University, Japan

Email: Makoto Nakamuta - nakamuta@qmed.hosp.go.jp; Kazuhiro Kotoh - kotoh-k@intmed3.med.kyushu-u.ac.jp; Munechika Enjoji* - enjoji@intmed3.med.kyushu-u.ac.jp; Eiji Kajiwara - kajiwara@med.shinnnittetu.ac.jp; Junya Shimono - juns@intmed3.med.kyushu-u.ac.jp; Akihide Masumoto - masumoto@med.kokura-hosp.ac.jp; Toshihiro Maruyama - toshima@med.kitakyushu-med.ac.jp; Norihiro Furusyo - furusho@intmed.med.kyushu-u.ac.jp; Hideyuki Nomura - hnomura@med.med.kyushu-u.ac.jp; Hironori Sakai - sakai@intmed3.med.kyushu-u.ac.jp; Kazuhiro Takahashi - tak@intmed3.med.kyushu-u.ac.jp; Koichi Azuma - azuma@intmed2.med.kyushu-u.ac.jp; Shinji Shimoda - sshimoda@intmed1.med.kyushu-u.ac.jp; Yuichi Tanabe - tanabe-y@fukuoka-shimin.ac.jp; Jun Hayashi - hayashi@intmed3.med.kyushu-u.ac.jp

* Corresponding author

Published: I May 2007

Comparative Hepatology 2007, 6:3 doi:10.1 186/1476-5926-6-3
Received: 7 July 2005

Accepted: I May 2007

This article is available from: http://www.comparative-hepatology.com/content/6/1/3

(C) 2007 Nakamuta et al; licensee BioMed Central Ltd.

This is an Open Access article distributed under the terms of the Creative Commons Attribution License (http://creativecommons.org/licenses/by/2.0), which permits unrestricted use, distribution, and reproduction in any medium, provided the original work is properly cited.

\begin{abstract}
Background: Lamivudine treatment has been recently demonstrated to increase the serum albumin levels in cirrhotic patients with hepatitis $B$ virus (HBV) infection, but the precise mechanism remains unclear. We hypothesized that the improvement of hypoalbuminemia by lamivudine may be attributable to the reduction of HBV replication itself, rather than to cessation of hepatitis. In order to confirm this hypothesis, in this study we evaluated factors which correlated with the increase in serum albumin levels. Fifty-four patients (Child-Pugh A/B/C, 35/9/I0) with HBV-related liver cirrhosis who had been treated with lamivudine for more than 12 months were evaluated. We analyzed the correlation between the increase in serum albumin levels at month 12 after starting treatment ( $\Delta$-albumin) and various pretreatment variables. We also analyzed the correlation between $\Delta$-albumin and the reduction in serum levels of HBV-DNA ( $\Delta$-HBV-DNA) or alanine aminotransferase $(\Delta-\mathrm{ALT})$ at month 12 .
\end{abstract}

Results: The average $\Delta$-albumin was $0.38 \mathrm{~g} / \mathrm{dL}$ and only serum HBV-DNA levels before treatment correlated significantly with $\Delta$-albumin. We also analyzed the correlation in patients whose alanine aminotransferase levels were normalized after 12 months so that the possible influence of breakthrough hepatitis could be excluded. Even among this subgroup of patients, there was no significant correlation between $\Delta$-albumin and either pretreatment alanine aminotransferase 
levels or $\Delta$-ALT. In contrast, in patients whose serum HBV-DNA was undetectable at month I2, we found a significant correlation between $\Delta$-albumin and both pretreatment serum HBV-DNA levels and $\Delta$-HBV-DNA.

Conclusion: Our results demonstrated that albumin levels are associated with pretreatment HBV-DNA but not with alanine aminotransferase levels.

\section{Background}

Chronic hepatitis $\mathrm{B}$ is an important cause of morbidity and mortality resulting from cirrhosis-related liver failure and hepatocelluar carcinoma (HCC) [1-3]. Lamivudine, a nucleoside analogue with potent antiviral effects against hepatitis B virus (HBV), has been shown to be effective both in patients with chronic hepatitis and also those with liver cirrhosis [4-6]. In cirrhotic patients, decreased HBVDNA loads following lamivudine treatment result in decreased serum levels of alanine aminotransferase (ALT), increased serum albumin levels, and improvement of the Child-Pugh score [7-13]. The underlying mechanism for the increase in albumin levels after lamivudine treatment has not been determined. It has been suggested that the improvement of hypoalbuminemia may be attributable to the cessation of hepatic inflammation. However, earlier treatments such as glycyrrhizin, ursodeoxycholic acid $[14,15]$, predonisolone [16], and Stronger NeoMinophagen $\mathrm{C}$ therapy [17], all of which reduce ALT levels in viral cirrhotic patients, do not result in improvement of hypoalbuminemia. Furthermore, it has been shown that there is no significant correlation between serum ALT levels and HBV-DNA loads in patients with HBV [18-20]. We hypothesized that the improvement of hypoalbuminemia by lamivudine may be attributable to the reduction of HBV replication itself, rather than to cessation of hepatitis. In order to confirm this hypothesis, we evaluated several laboratory parameters in cirrhotic patients treated with lamivudine that could influence serum albumin levels.

\section{Results}

Fifty-four cirrhotic patients with HBV infection were analyzed (Table 1, see Materials and methods). Before the treatment, there was no significant correlation between either serum ALT or albumin levels and HBV-DNA loads in our patients (data not shown). Following lamivudine treatment, the levels of HBV-DNA and ALT rapidly decreased while albumin levels simultaneously increased (Figure 1). HBV-DNA levels decreased significantly from $6.59 \pm 0.18 \log$ copies $/ \mathrm{mL}$ to $2.98 \pm 0.12 \log$ copies $/ \mathrm{mL}$ at 3 months after treatment $(p<0.01)$, and decreased further to $2.87 \pm 0.14 \log$ copies/mL and $2.94 \pm 0.18$ log copies/ $\mathrm{mL}$ at 6 and 9 months, respectively. Similarly, ALT levels also decreased significantly from $102.1 \pm 10.4 \mathrm{U} / \mathrm{L}$ to 42.0 $\pm 2.7 \mathrm{U} / \mathrm{L}$ at 3 months after treatment $(p<0.01)$, and to $38.8 \pm 4.1 \mathrm{U} / \mathrm{L}$ and $33.1 \pm 2.4 \mathrm{U} / \mathrm{L}$ at 6 and 9 months, respectively. However, at 12 months there was a slight increase in both HBV-DNA and ALT levels $(3.17 \pm 0.21 \mathrm{log}$ copies/mL and $44.3 \pm 8.6 \mathrm{U} / \mathrm{L}$, respectively), although the differences between values at 9 and 12 months were not statistically significant. The serum levels of albumin increased from $3.56 \pm 0.09 \mathrm{~g} / \mathrm{dL}$ to $3.76 \pm 0.08 \mathrm{~g} / \mathrm{dL}$ at 3 months after treatment, and increased further to $3.89 \pm$ $0.08 \mathrm{~g} / \mathrm{dL}(p<0.05)$ and $3.95 \pm 0.08(p<0.01) \mathrm{g} / \mathrm{dL}$ at 6 and 9 months, respectively. At 12 months, albumin levels remained steady at $3.94 \pm 0.08 \mathrm{~g} / \mathrm{dL}$.

To identify the factors associated with increased serum albumin levels, correlations between the increase in serum albumin levels at 12 months after the start of treatment ( $\Delta$-albumin) and basic variables before treatment were examined using the data for all patients. In this anal-

Table I: Characteristics of the patients

\begin{tabular}{|c|c|c|c|c|}
\hline & Child A & Child B & Child C & Total \\
\hline$n$ & 35 & 9 & 10 & 54 \\
\hline Male/female & $26 / 9$ & $7 / 2$ & $5 / 5$ & $38 / 16$ \\
\hline Age & $53.0 \pm 9.1$ & $54.9 \pm 4.6$ & $49.5 \pm 9.1$ & $52.6 \pm 8.8$ \\
\hline Albumin $(\mathrm{g} / \mathrm{dL})$ & $3.85 \pm 0.43$ & $3.12 \pm 0.38$ & $2.94 \pm 0.57$ & $3.56 \pm 0.6$ \\
\hline Bilirubin (mg/dL) & $0.90 \pm 0.43$ & $1.25 \pm 0.35$ & $3.09 \pm 1.28$ & $1.37 \pm 1.07$ \\
\hline $\mathrm{ALT}(\mathrm{U} / \mathrm{L})$ & $118.2 \pm 125.5$ & $62.7 \pm 43.2$ & $80.6 \pm 96.8$ & $102.0 \pm 113.0$ \\
\hline Platelet $\left(\times 10^{4} / \mu \mathrm{L}\right)$ & $11.8 \pm 5.3$ & $7.3 \pm 3.2$ & $6.3 \pm 2.5$ & $10.0 \pm 5.2$ \\
\hline $\mathrm{HBeAg}(+/-)$ & $17 / 18$ & $6 / 3$ & $6 / 4$ & $29 / 25$ \\
\hline \multicolumn{5}{|l|}{ HBV-DNA (log copies/mL) } \\
\hline$<5.0$ & 1 & 1 & 2 & 4 \\
\hline $5.0 \leq x<7.0$ & 21 & 4 & 3 & 28 \\
\hline$\geq 7.0$ & 13 & 4 & 5 & 22 \\
\hline
\end{tabular}




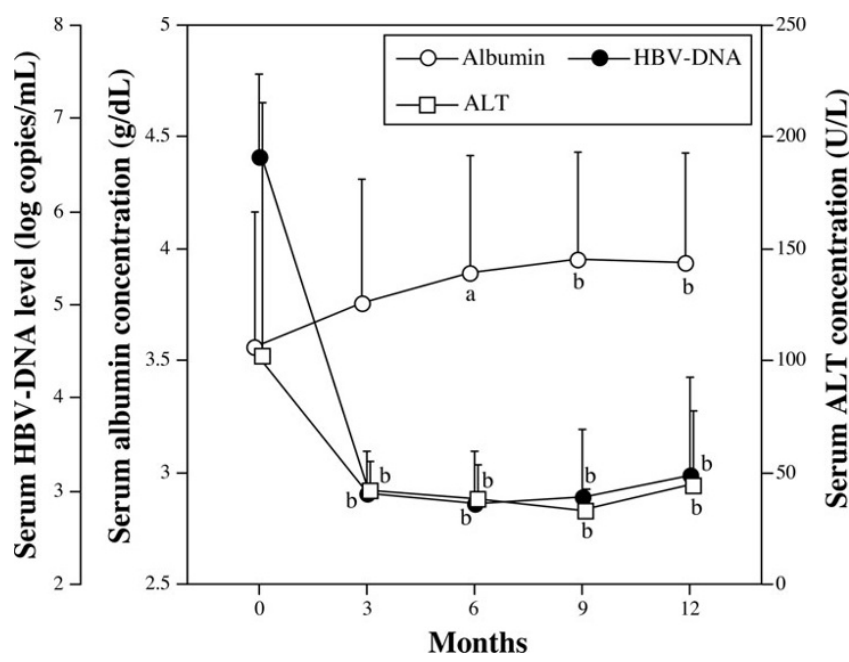

Figure I

Time course of albumin, HBV-DNA, and ALT levels in lamivudine treatment. The average serum levels of albumin (closed circles), HBV-DNA (open squares), and ALT (open circles) at 3-month intervals from the start of lamivudine therapy are plotted. Soon after the start of treatment, serum albumin levels increased rapidly and simultaneously with a decrease in HBV-DNA and serum ALT levels. The data represent mean $+\mathrm{SD}(\mathrm{a}, \mathrm{b} ; p<0.05$ and $p<0.01$ vs. 0 month, respectively).

ysis, only HBV-DNA load correlated significantly with $\Delta$ albumin $\left(\mathrm{t}=2.66, \mathrm{r}^{2}=0.120089, p=0.0103\right)$, whereas age, sex, HBeAg, ALT, bilirubin, platelet count, and ChildPugh classification did not (Table 1).

Although we found no correlation between $\Delta$-albumin and pretreatment serum ALT levels for the entire patient population, the possibility remained that breakthrough hepatitis or continuous elevation of ALT might interfere with $\Delta$-albumin. Indeed, two patients showed breakthrough hepatitis, where ALT levels increased to over 100 $\mathrm{U} / \mathrm{L}$, and 20 patients still showed abnormally high ALT (> $35 \mathrm{U} / \mathrm{L})$ at 12 months after treatment. We next evaluated the correlation between $\Delta$-albumin and pretreatment serum ALT levels among the 32 patients in whom serum ALT levels were normalized $(<35 \mathrm{U} / \mathrm{L})$ at 12 months after the start of therapy. As shown in Figure 2A, there was no significant correlation between $\Delta$-albumin and pretreatment serum ALT levels in this subgroup of patients $(r=$ $0.083, p=0.64)$. We also evaluated the correlation between $\Delta$-albumin and reduction in ALT levels at month 12 after starting treatment ( $\Delta$-ALT) in this group, but there was still no significant correlation between $\Delta$-albumin and $\Delta$-ALT $(r=0.0685, p=0.67)$ (Figure $2 \mathrm{~B})$.

Furthermore, we evaluated the correlation between $\Delta$ albumin and serum HBV-DNA levels before treatment
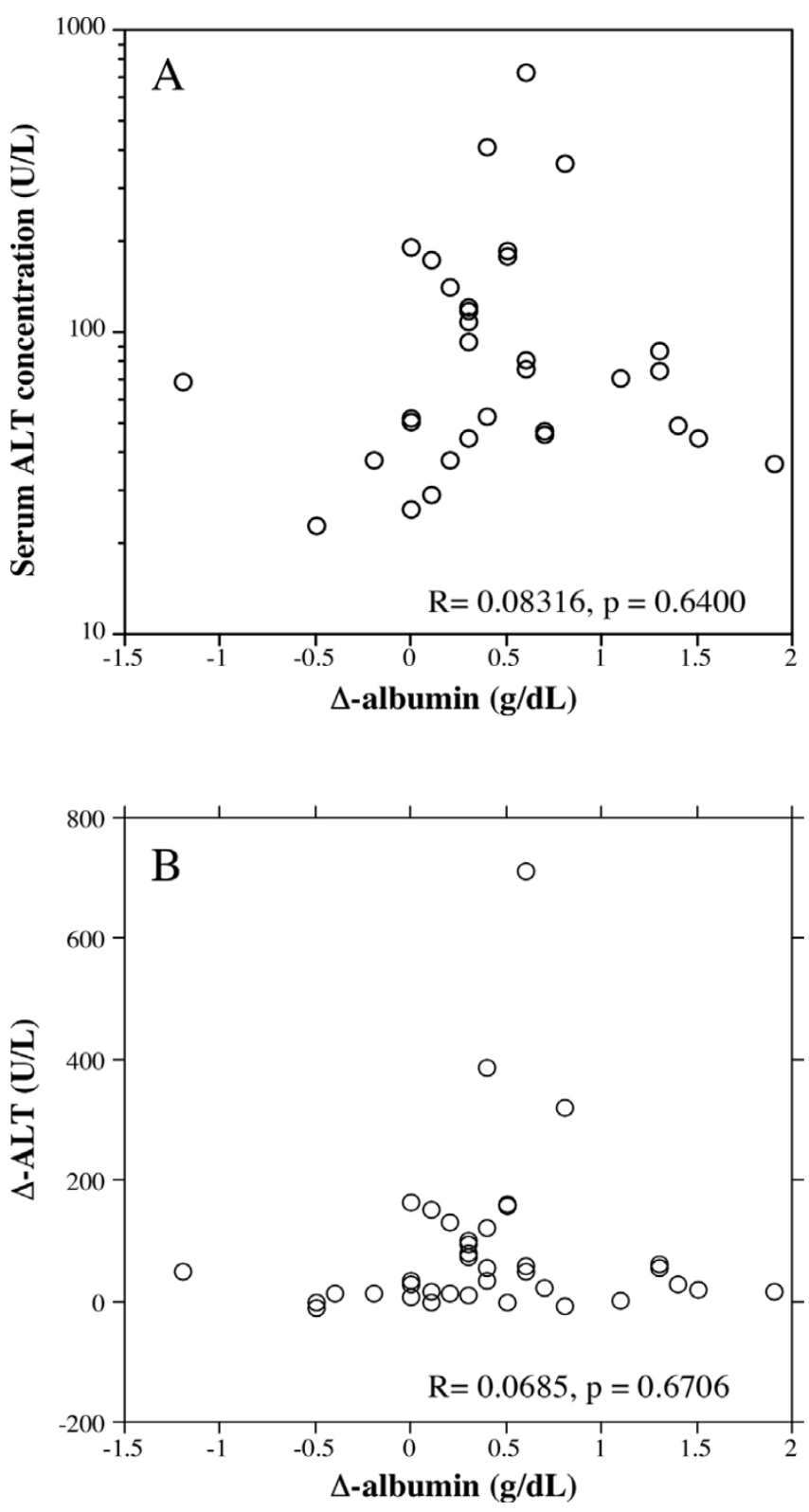

Figure 2

Correlation between ALT levels before treatment and $\Delta$-albumin (A), and $\Delta$-ALT and $\Delta$-albumin (B). In patients whose serum ALT levels were normalized at 12 months after treatment, there was no significant correlation $\Delta$-albumin and pretreatment serum ALT levels (A). There was also no significant correlation $\Delta$-albumin and $\Delta$-ALT (B).

among the 41 patients in whom serum HBV-DNA levels were undetectable at 12 months post-treatment. In this analysis, we found a significant correlation between $\Delta$ albumin and the serum levels of HBV-DNA before the start of therapy $(r=0.42459, p<0.0001)$ (Figure 3A). We also evaluated the correlation between $\Delta$-albumin and reduction in HBV-DNA levels at month 12 after starting 

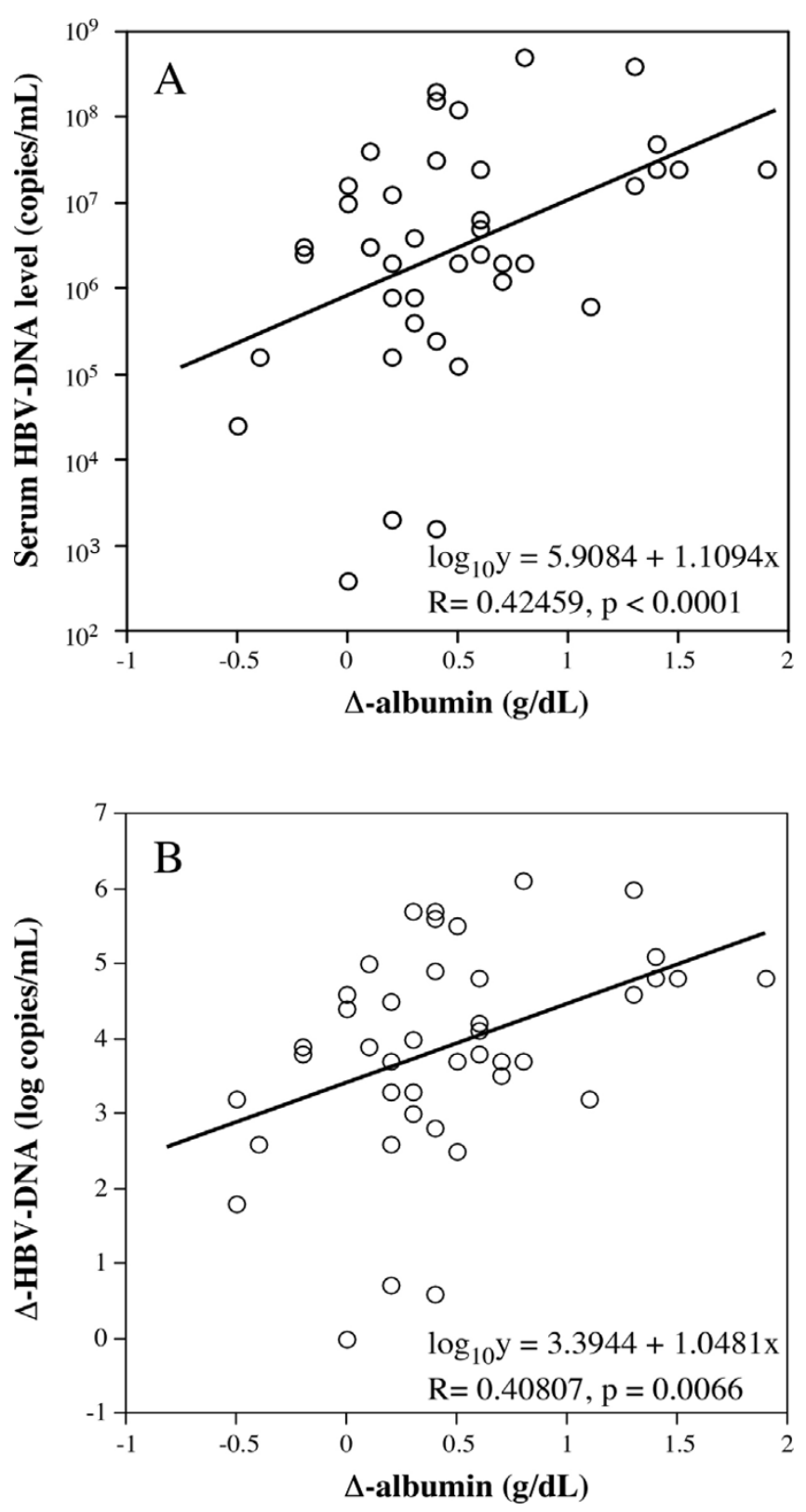

Figure 3

Correlation between HBV-DNA levels before treatment and $\Delta$-albumin (A), and $\Delta$-HBV-DNA and $\Delta$ albumin (B). Patients whose serum HBV-DNA was undetectable at 12 months after treatment, there was a significant correlation between $\Delta$-albumin and both pretreatment serum HBV-DNA levels (A) and $\triangle$-HBV-DNA (B).

treatment ( $\Delta$-HBV-DNA) in this group, and we again found that $\Delta$-albumin significantly correlated with $\Delta$ HBV-DNA $(r=0.40807, p=0.0066)$ (Figure 3B).

\section{Discussion}

This study demonstrated the followings: 1) HBV-DNA, but not ALT levels, before lamivudine treatment was asso- ciated with increased serum albumin levels at 12 months after treatment ( $\Delta$-albumin); 2) Even among those patients who showed cessation of hepatitis following treatment, there was no correlation between either pretreatment ALT levels or $\Delta$-ALT and $\Delta$-albumin; 3 ) In contrast, in the analysis of subjects with undetectable HBVDNA levels after treatment, there was significant correlation between both pretreatment HBV-DNA levels and $\Delta$ HBV-DNA and $\Delta$-albumin. Taken together, these results suggest that the improvement of hypoalbuminemia following lamivudine treatment is attributable to a reduction of HBV replication, but not to cessation of hepatitis.

We do not deny the idea that cessation of hepatitis, which is represented by lowering of serum ALT levels, contributed to and increase of serum albumin levels. In true, we think that replicative HBV and inflammation are closely related; however, in our study, HBV reduction statistically showed more effect improving serum albumin levels than decreasing the inflammation marker ALT. This may happen perhaps because, in cirrhotic patients, fibrosis is the main pathological change (compared with inflammation), and the correlation between, on the one hand, serum albumin or HBV-DNA levels and, on the other hand, ALT levels was in some degree weakened as the cirrhotic change proceed. Therefore, in cirrhotic patients, $\Delta$ ALT is within a narrower range and ALT levels cannot influence albumin levels significantly.

How does lowering of HBV load induces the increase of albumin levels in an inflammation-independent manner? Hui et al. [7] recently showed that emergence of phenotypic resistance of HBV-DNA was associated with a rapid decline in serum albumin levels following prolonged lamivudine treatment, although they did not report whether a correlation existed between serum ALT levels and serum HBV loads. In a series of studies in woodchucks and Hep G2 cells, Kosovsky et al. demonstrated that HBV replication inversely correlated with cell proliferation and DNA synthesis by hepatocytes [21-23]. Yang et al. has analyzed gene expression profiles of HepG2 cells with or without HBV [24]. However, whether HBV replication directly influences the ability of infected hepatocytes to synthesize protein is still unclear and further studies are needed.

Our results indicate that increased serum albumin levels should be expected in cirrhotic patients following lamivudine treatment, and that this occurs independently of serum ALT levels and Child-Pugh's score before treatment, as shown by the lack of a correlation between those variables and $\Delta$-albumin. Previous studies of lamivudine treatment for liver cirrhosis showed that fatalities occur because of acute liver failure after discontinuation of lamivudine $[25,26]$ or emergence of lamivudine-resistance mutants $[27,28]$. Recent reports, however, indicate that 
Table 2: Correlations between $\Delta$-albumin and basic variables before treatment

\begin{tabular}{lccc}
\hline & $\mathrm{t}$ & $\mathrm{R}^{2}$ & $\mathrm{P}$-value \\
\hline Age & -0.14 & 0.000398 & 0.8873 \\
ALT & 0.67 & 0.008536 & 0.5064 \\
Bilirubin & -0.04 & 0.000036 & 0.9659 \\
Platelet & -0.87 & 0.014279 & 0.3894 \\
HBV-DNA & 2.66 & 0.120089 & 0.0103 \\
HBeAg (+/-) & - & - & 0.6201 \\
Sex (male/female) & - & - & 0.4251 \\
Child-Pugh's classification & - & - & 0.0968 \\
\hline
\end{tabular}

prolonged use of lamivudine for cirrhotic patients is safe and effective $[5,29,30]$. Furthermore, since adefovir is effective for treating resistant mutants [31-33], lamivudine therapy should be encouraged. Hypoalbuminemia, which causes ascites, edema, and hydrothorax, lowers the quality of life of cirrhotic patients [34,35]. High viral load of HBV is associated with higher mortality and morbidity in cirrhotic patients in consequence of high occurrence or recurrence rate of HCC [36,37]. Lamivudine is effective for preventing or delaying occurrence of liver failure and HCC through lowering HBV, and therefore can be a first choice drug for patients with high HBV levels regardless of serum ALT levels.

\section{Methods \\ Patients}

A total of 54 cirrhotic patients with HBV infection were evaluated, including 38 males and 16 females, ranging in age from 28 to 71 years (mean 52.6 years) (Table 1 ). Informed consent was obtained from each patient prior to their entering the study. Liver cirrhosis was diagnosed based on liver biopsy $(\mathrm{n}=11)$, laboratory data, ultrasonography, and/or computed tomography. Patients were classified as Child-Pugh class A, B and C (35, 9, and 10 patients, respectively). For all patients, the existence of serum HBV-DNA was confirmed by TMA assay $\left(10^{3.7}\right.$ $10^{8.7}$ genome equivalents $/ \mathrm{mL} ; 3.7-8.7$ log genome equivalents $[\mathrm{LGE}] / \mathrm{mL}$ ) (Chugai Diagnostic Science, Tokyo, Japan) or by a Roche Monitor kit $\left(10^{2.6}-10^{7.6}\right.$ copies $/ \mathrm{ml}$; 2.6-7.6 log copies $/ \mathrm{mL}$ ) (Roche Diagnostics, Tokyo, Japan) before treatment. HBe-Ag was positive in 29 patients and negative in 25 patients. Patients with fatty liver, viral hepatitis C, a history of alcohol abuse, or autoimmune disorders such as autoimmune hepatitis and primary biliary cirrhosis were excluded. None of the patients had a prior history of treatment for hepatocellular carcinoma.

Patients had been treated with lamivudine $(100 \mathrm{mg}$, once a day) without interruption for more than twelve months at Kyushu University Hospital and its affiliated hospitals. Basic laboratory data, such as platelet counts, serum ALT levels, bilirubin, albumin, serum HBV-DNA load (Roche
Monitor kit: Roche Diagnostics) and HBe-Ag were determined at least every 3 months.

\section{Statistical analysis}

Data are expressed as mean $\pm \mathrm{SD}$, and statistical comparisons were performed using chi-squared test for categorical data and one-way ANOVA for numeric data. In cases where the serum HBV-DNA load was less than $2.6 \mathrm{log}$ copies $/ \mathrm{mL}$, it was entered as $2.6 \log$ copies $/ \mathrm{mL}$. For the analysis of correlations between two continuous variables, a simple regression model was used. For the analysis of discontinuous variables, such as sex and HBe-Ag, statistical differences were confirmed using Mann-Whitney U test or Kruskal-Wallis test.

\section{Competing interests}

The author(s) declare that they have no competing interests.

\section{Authors' contributions}

$\mathrm{MN}$ and ME participated in the experimental design and writing of the manuscript. JH participated in the experimental design. KK performed most of the analysis. YT, EK, JS, AM, TM, NF, HN, HS, KT, KA, and SS collected and supplied the clinical data of patients.

\section{Acknowledgements}

In addition to the authors, the Kyushu University Liver Disease Study Group includes the following individuals: R Sugimoto (Harasanshin Hospital, Fukuoka), H Amagase and S Tominaga (Mihagino Hospital, Kitakyushu), K Yanagita (Saiseikai Karatsu Hospital, Karatsu), K Ogiwara (Kyushu Rosai Hospital, Kitakyushu), M Tokumatsu (Saiseikai Fukuoka Hospital, Fukuoka), S Tabata (Hayashi Hospital, Fukuoka), M Yokota (National Kyushu Cancer Center, Fukuoka), H Tanaka (Chihaya Hospital, Fukuoka), S Nagase (Fukuoka Teishin Hospital, Fukuoka), S Tsuruta (Nakabaru Hospital, Fukuoka), S Tada (Moji Rosai Hospital, Kitakyushu), M Nagano (Kyushu Koseinenkin Hospital, Kitakyushu), M Honda (Nishi-Fukuoka Hospital, Fukuoka), T Umeno (Sawara Hospital, Fukuoka), T Sugimura (National Hospital Organization Fukuoka Higashi Hospital, Fukuoka), S Ueno (Kitakyushu Municipal Wakamatsu Hospital, Kitakyushu), K Miki (Kitakyushu Municipal Moji Hospital, Kitakyushu), H Okubo (Shineikai Hospital, Kitakyushu), H Fujimoto (Mitusbishikagaku Hospital, Kitakyushu), N Higuchi (Shin-Nakama Hospital, Kitakyushu), S Shigematsu (Kouseikan Hospital, Saga), and N Higashi (National Hospital Organization Beppu Hospital, Ohita). We would like to thank them for their assistance. 


\section{References}

I. Ganem D, Prince AM: Hepatitis B virus infection - natural history and clinical consequences. $N$ Engl J Med 2004, 350: I I 18-1 I29.

2. Lai CL, Ratziu V, Yuen M-F, Poynard T: Viral hepatitis B. Lancet 2003, 362:2089-2094.

3. Tang ZY: Hepatocellular carcinoma-cause, treatment and metastasis. World / Gastroenterol 200I, 7:445-454.

4. Ooga H, Suzuki F, Tsubota A, Arase Y, Suzuki Y, Akuta N, Sezaki H, Hosaka T, Someya T, Kobayashi M, Saitoh S, Ikeda K, Kobayashi M, Matsuda M, Satoh J, Kumada H: Efficacy of lamivudine treatment in Japanese patients with hepatitis B virus-related cirrhosis. J Gastroenterol 2004, 39: I078- 084

5. Cetin K, Sabahattin K, Kadir D, Ahmet D, Ziyaettin D, Selim B, Muruvvet B, Fatih B, Gungor B, Zeynel M, Yilmaz C, Atilla O: Lamivudine treatment in patients with hepatitis $B$ virus induced liver cirrhosis. Hepatogastroenterology 2003, 50(Suppl 2):ccxcv-ccxcvii.

6. Yao FY, Terrault NA, Freise C, Maslow L, Bass NM: Lamivudine treatment is beneficial in patients with severely decompensated cirrhosis and actively replicating hepatitis $B$ infection awaiting liver transplantation: a comparative study using a matched, untreated cohort. Hepatology 200I, 34:4II-4I6.

7. Hui JM, George J, Liddle C, Lin R, Samarasinghe D, Crewe E, Farrell GC: Changes in serum albumin during treatment of chronic hepatitis B with lamivudine: effects of response and emergence of drug resistance. Am J Gastroenterol 2002, 97: 1003-1009.

8. Villeneuve JP, Condreay LD, Willems B, Pomier-Layrargues G, Fenyves D, Bilodeau M, Leduc R, Peltekian K, Wong F, Margulies M, Heathcote EJ: Lamivudine treatment for decompensated cirrhosis resulting from chronic hepatitis B. Hepatology 2000, 3I:207-2I0.

9. Yao FY, Bass NM: Lamivudine treatment in patients with severely decompensated cirrhosis due to replicating hepatitis B infection. J Hepatology 2000, 33:301-307.

10. Kapoor D, Guptan RC, Wakil SM, Kazim SN, Kaul R, Agarwal SR Raisuddin S, Hasnain SE, Sarin SK: Beneficial effects of lamivudine in hepatitis B virus-related decompensated cirrhosis. J Hepatology 2000, 33:308-3 I2.

II. Sponseller CA, Bacon BR, Di Bisceglie AM: Clinical improvement in patients with decompensated liver disease caused by hepatitis B after treatment with lamivudine. Liver Transpl 2000, 6:7I5-720

12. Perrillo RP, Wright T, Rakela J, Levy G, Schiff E, Gish R, Wartin P Dienstag J, Adams P, Dickson R, Anschuetz G, Bell S, Condreay L, Brown N, The Lamivudine North American Transplant Group: A multicenter United States-Canadian trial to assess lamivudine monotherapy before and after liver transplantation for chronic hepatitis B. Hepatology 200I, 33:424-432

13. Andreone P, Biselli M, Gramenzi A, Cursaro C, Morelli MC, Sama C, Lorenzini S, Spinucci G, Porzio F, Felline F, Di Giammarino L, Bernardi $M$ : Efficacy of lamivudine therapy for advanced liver disease in patients with precore mutant hepatitis B virus infection awaiting liver transplantation. Transplantation 2002, 74: I I 19-I I 24.

14. Scotto G: The ursodeoxycholic acid for the treatment of HCV infections. Infez Med 1997, 5:168-173.

15. Matsuda $Y$, Inada $M$, Maeda $H$, Matsuyama $T$ : Improvement of alanine aminotransferase by administration of suplatast tosilate plus ursodeoxycholic acid in patients with resistance to ursodeoxycholic acid monotherapy on hepatitis $\mathbf{C}$ virusrelated chronic liver disease. Intern Med 2002, 41:774-779.

16. Lee SD, Tong MJ, Wu JC, Lin HC, Tsai YT, Lo KJ: A randomised double-blind placebo-controlled trial of prednisolone therapy in $\mathrm{HBeAg}$ and HBV DNA positive Chinese patients with chronic active hepatitis B. I Hepatol I99I, I 2:246-250.

17. Miyake K, Tango T, Ota Y, Mitamura K, Yoshiba M, Kako M, Hayash S, Ikeda Y, Hayashida N, Iwabuchi S, Sato Y, Tomi T, Funaki N, Hashimoto N, Umeda T, Miyazaki J, Tanaka K, Endo Y, Suzuki H: Efficacy of Stronger Neo-Minophagen $C$ compared between two doses administered three times a week on patients with chronic viral hepatitis. I Gastroenterol Hepatol 2002 17:1 198-1204.

18. Yalcin K, Degertekin H, Yildiz F, Celik Y: Markers of disease activity in chronic hepatitis B virus infection. Clin Invest Med 2003 26:27-34.
19. Sakugawa H, Nakasone H, Nakayoshi T, Kawakami Y, Yamashiro T, Maeshiro T, Kinjo F, Saito A: Correlation between serum transaminase activity and virus load among patients with chronic liver disease type B. Hepatol Res 2001, 21:159-168.

20. Chun YK, Kim JY, Woo HJ, Oh SM, Kang I, Ha J, Kim SS: No significant correlation exists between core promoter mutations, viral replication, and liver damage in chronic hepatitis B infection. Hepatology 2000, 32: I I 54- I I 62

21. Kosovsky MJ, Khaoustov VI, Rushton M, Yoffe B: Induction of hepatitis $B$ virus gene expression at low temperature. Biochim Biophys Acta 2000, I 490:63-73.

22. Fourel I, Cullen JM, Saputelli J, Aldrich CE, Schaffer $P$, Averett DR Pugh J, Mason WS: Evidence that hepatocyte turnover is required for rapid clearance of duck hepatitis $B$ virus during antiviral therapy of chronically infected ducks. J Virol 1994, 68:832I-8330.

23. Kajino K, Jilbert AR, Saputelli J, Aldrich CE, Cullen J, Mason WS: Woodchuck hepatitis virus infections: very rapid recovery after a prolonged viremia and infection of virtually every hepatocyte. I Virol 1994, 68:5792-5803.

24. Yang J, Bo CB, Yao J, Yang NM, Wang SQ: Diffeentially expressed cellular genes following HBV: potential targets of anti-HBV drugs? I Viral Hepatitis 2005, I2:357-363.

25. Wang JH, Lu SN, Lee CM, Lee JF, Chou YP: Fatal hepatic failure after emergence of the hepatitis $B$ virus mutant during lamivudine therapy in a patient with liver cirrhosis. Scand ] Gastroenterol 2002, 37:366-369.

26. Lim SG, Wai CT, Rajnakova A, Kajiji T, Guan R: Fatal hepatitis B reactivation following discontinuation of nucleoside analogues for chronic hepatitis B. Gut 2002, 5 I:597-599.

27. Kagawa T, Watanabe N, Kanouda H, Takayama I, Shiba T, Kanai T, Kawazoe K, Takashimizu S, Kumaki N, Shimamura K, Matsuzaki S, Mine T: Fatal liver failure due to reactivation of lamivudineresistant HBV mutant. World I Gastroenterol 2004, I 0: I 686- I687.

28. Bruno R, Sacchi P, Filice C, Filice G: Acute liver failure during lamivudine treatment in a hepatitis B cirrhotic patient. Am ] Gastroenterol 2001, 96:265.

29. Hadziyannis SJ, Papatheodoridis GV, Dimou E, Laras A, Papaioannou $C$ : Efficacy of long-term lamivudine monotherapy in patients with hepatitis B e antigen-negative chronic hepatitis B. Hepatology 2000, 32:847-85I.

30. Nakamuta M, Kotoh K, Tanabe Y, Kajiwara E, Shimono J, Masumoto A, Maruyama T, Furusyo N, Nomura H, Sakai H, Takahashi K, Azuma K, Shimoda S, Enjoji M, Hayashi J, Kyushu University Liver Disease Study Group: Body surface area is an independent factor contributing to the effects of lamivudine treatment. Heptol Res 2005, 3 I: : 3-17.

3I. Kuwahara R, Kumashiro R, Inoue H, Tanabe R, Tanaka E, Hino T, Ide $T$, Koga Y, Sata M: Adefovir dipivoxil as a treatment for hepatic failure caused by lamivudine-resistant HBV strains. Dig Dis $\mathrm{SCl}$ 2004, 49:300-303.

32. Wiegand J, Tischendorf JJ, Nashan B, Klempnauer J, Flemming P, Niemann $P$, Rohde $P$, Manns MP, Trautwein C, Tillmann HL: Severe exacerbation of chronic hepatitis B after emergence of lamivudine resistance in a cirrhotic patient: immediate switch to adefovir dipivoxil appears to be indicated. J Gastroenterol 2004, 42:15-18.

33. Tong MJ, Tu SS: Treatment of patients with chronic hepatitis B with adefovir dipivoxil. Semin Liver Dis 2004, 24(Suppl I):37-44.

34. Kotoh K, Nakamuta M, Fukushima M, Matsuzaki C, Enjoji M, Sakai H, Nawata $\mathrm{H}$ : High relative fat-free mass is important for maintaining serum albumin levels in patients with compensated liver cirrhosis. World / Gastroenterol 2005, I I: | 356- | 360.

35. Arroyo V: Pathophysiology, diagnosis and treatment of ascites in cirrhosis. Ann Hepatol 2002, I:72-79.

36. Tseng $\mathrm{P}$, Lu S-N, Tung H-D, Wang J-H, Changchien C-S, Lee C-M Determinants of early mortality and benefits of lamivudine therapy in patients with hepatitis B virus-related decompensated liver cirrhosis. I Viral Hepatitis 2005, I 2:386-392

37. Mahmood S, Niiyama G, Kamei A, Izumi A, Nakata K, Ikeda H, Suehiro M, Kawanaka M, Togawa K, Yamada G: Influence of viral load and genotype in the pregression of hepatitis $B$-associated liver cirrhosis to hepatocellular carcinoma. Liver Int 2005, 25:220-225 